\title{
PENGARUH PENGGUNAAN STRATEGI SOCIO SCIENTIFIC ISSUES TERHADAP REFLECTIVE JUDGMENT SISWA KELAS IX DI SMP NEGERI 11 BANDAR LAMPUNG
}

\author{
${ }^{1}$ Fitria Wulandari, ${ }^{2}$ Akbar Handoko dan ${ }^{3}$ Bambang Sri Anggoro \\ ${ }^{1}$ Mahasiswi Prodi Pendidikan Fakultas Tarbiyah dan Keguruan, Universitas Islam Negeri \\ Raden Intan. J1. H Endro Suratmin Sukarame-Bandar Lampung (0721)70326). \\ ${ }^{2,3}$ Dosen Prodi Pendidikan Biologi Fakultas Tarbiyah dan Keguruan, Universitas Islam \\ Negeri Raden Intan.Jl. H Endro Suratmin Sukarame-Bandar Lampung (0721)70326): \\ akbar.handoko@radenintan.ac.id
}

Diterima: 05 Mei 2017. Disetujui : 19 Juni 2017. Dipublikasikan: 29 Juni 2017

\begin{abstract}
Abstrak: Penelitian yang telah dilakukan merupakan jenis penelitian quasy eksperimen. Penelitian dilaksanakan di SMPN 11 Bandar Lampung yang bertempat di Jl. Sentot Kel. Ketapang Kec. Panjang Bandar Lampung. Penelitian bertujuan untuk mengetahui pengaruh strategi socio scientific issues terhadap reflective judgment siswa kelas IX SMPN 11 Bandar Lampung pada materi sistem reproduksi. Desaian penelitian yang digunakan adalah The Matching only posttest control group design. Alat pengumpulan data yang digunakan adalah tes, lembar observasi dan dokumentasi. Sedangkan untuk instrument pada penelitian terdiri dari tes essay yang indikator disesuaikan dengan tahapan pemikiran reflective. Hasil penelitian berupa data kuantitaif, data yang digunakan dalam penelitian yaitu tes berupa soal essay yang digunakan untuk mengetahui reflective judgment siswa. Uji hipotesis penelitian menggunakan ujit, sebelum dilakukan uji $t$ data diuji dulu menggunakan uji prasyarat yaitu uji normalitas dan uji homogenitas. Dari hasil penelitian didapatkan bahwa pembelajaran dengan menggunakan strategi Socio scientific issues kelas eksperimen diperoleh nilai posttestrata-rata 74,42 dan pada kelas kontrol diperoleh nilai rata-rata 70,73. Untuk uji $t$ pada posttes diperoleh data $\mathrm{t}_{\text {hitung }}=10,0882523 \mathrm{t}_{\mathrm{tabel}(0,05)}=1,6669$. Jadi dapat disimpulkan bahwa strategi pembelajaran Socio scientific issues berpengaruh positif terhadap hasil nilai posttes, dengan pembelajaran berbasis SSI dapat mempengaruhi Reflective judgment siswa sehingga saat disajikan suatu masalah atau isu-isu sosial lebih bijaksana dalam pengambilan keputusan yang baik.
\end{abstract}

Kata kunci: Strategi Socio scientific issues, Reflective judgment

\section{PENDAHULUAN}

Pendidikan tidak dapat dipisahkan dari kehidupan manusia, memiliki peranan penting untuk perkembangan masyarakat dan harus disertai dengan tujuan yang telah ditentukan agar dapat berjalan dengan baik.Tujuan pendidikan memuat gambaran tentang nilai-nilai yang baik, luhur, pantas, benar, dan indah untuk kehidupan. Pendidikan memiliki dua fungsi yaitu memberikan arah kepada segenap kegiatan pendidikan dan merupakan sesuatu yang ingin dicapai oleh segenap kegiatan pendidikan.

Pendidikan tidak lepas dari kegiatan belajar. Belajar merupakan usaha seseorang untuk memperoleh suatu perubahan tingkah laku yang baru secara 
keseluruhan sebagai hasil pengalaman sendiri dalam interaksi dilingkungan. Sudjana menjelaskan bahwa belajar adalah proses yang ditandai dengan adanya perubahan pada diri seseorang. Perubahan sebagai hasil proses belajar dapat dilihat dalam berbagai bentuk seperti berubah pengetahuannya, pemahamannya, sikap dan tingkah lakunya, keterampilannya dan kecakapannya, daya reaksinya, daya penerimaannya dan lain-lain aspek pada individu ( Sujdana, 1986). Dalam proses belajar tersebut, seseorang dapat menemukan pengetahuan dan pengalaman baru dari lingkungannya, dengan demikian seseorang mampu melakukan perubahan tingkah laku secara keseluruhan.

Pembelajaran biologi merupakan bagian dari pendidikan IPA, mengupayakan terbentuknya subyek didik sebagai manusia yang memiliki modal literasi sains, yaitu manusia yang membuka kepekaan diri, mencermati, menyaring, mengaplikasikan, serta turut serta berkontribusi bagi perkembangan sains dan teknologi untuk peningkatan kesejahteraan dan kemaslahatan masyarakat. Kemajuan teknologi merupakan sesuatu yang tidak bisa dihindari oleh manusia dalam kehidupan, kemajuan teknologiberjalan sesuai dengan kemajuan ilmu pengetahuan. Setiap inovasi diciptakan untuk memberikan manfaat positif bagi kehidupan manusia, kemudahan serta sebagai cara baru dalam melakukan aktifitas manusia.

Pengikisan nilai moral manusia sangat mengkhawatirkan, semua itu tidak lepas dari pesatnya perkembangan dan kemajuan teknologi. Perkembangan teknologi langsung maupun tidak langsung mempengaruhi perkembangan moral, seseorang dapat berperilaku buruk akibat penggunaan teknologi yang tidak pada tempatnya. Meleburnya norma dan nilai di masyarakat membuat generasi muda tidak lagi mengindahkan aturan, pergaulan bebas dan seks bebas sudah menjadi gaya hidup dikalangan remaja. Untuk itu perlu diadakan proses pembelajaran yang menitik beratkan pada materi sistem reproduksi.

Tugas utama keluarga bagi pendidikan anak ialah sebagai peletak dasar bagi pendidikan akhlak dan pandangan hidup keagamaan, sifat dan tabiat anak sebagian besar diambil dari orang tuanya dan dari anggota keluarga yang lain (Hasbullah, 2013). Sebagai lingkungan yang paling akrab dengan kehidupan anak, keluarga memiliki peranan penting dan strategis bagi penyadaran, penanaman, dan pengembangan nilai moral anak. Sekolah sebagai pertahanan kedua setelah keluarga, bertugas bukan hanya memberi materi pelajaran secara teori tetapi juga menanamkan moral yang baik pada diri siswa, sehingga mereka bukan saja berilmu tetapi juga berahklak mulia. SSI merupakan strategi yang bertujuan untuk menstimulasi perkembangan intelektual, moral dan etika, serta kesadaran perihal hubungan antara sains dengan kehidupan social (Brendan E. Callahan, 2009).

\section{METODE PENELITIAN}

Desain yang digunakan dalam penelitian ini adalah The Matching only posttest control group design. Dalam pola ini baik eksperimen maupun kontrol dikenakan posttest, tetapi hanya kelompok eksperimen yang mendapat perlakuan (Freankel JR and Wallen NE, 2008).Sampel yang diambil dalam penelitian terdiri dari dua kelas, yaitu kelas IX G sebagai kelas eksperimen dan kelas IX H sebagai kelas kontrol. Teknik yang digunakan dalam penelitian adalah menggunakan Sampling acak sederhana yaitu mencampur subjek-subjek didalam populasi sehingga semua subjek dianggap sama (Suharsimi Arikunto, 2006). Dengan 
demikian maka peneliti memberi hak yang sama kepada subjek untuk memperoleh kesempatan dipilih menjadi sampel. Analisis data penelitian menggunakan uji $t$ independent.

\section{HASIL PENELITIAN}

Hasil penelitian ini menunjukkan bahwa $t_{\text {hitung }}>t_{\text {tabel }}$ yang berarti $\mathrm{H}_{1}$ diterima dan $\mathrm{H}_{\mathrm{O}}$ ditolak. Hal tersebut menunjukkan bahwa terdapat pengaruh signifikan penggunaan strategisocio scientific issues terhadap reflective judgment siswa. Hasil perhitungan data menggunakan uji $t$ independent pada penelitian disajikan pada tabel dibawah ini.

Tabel 1.

Hasil Perhitungan Uji $t$

karakteristik Hasil Kesimpulan

$\mathrm{T}_{\text {hitung }}$

$\mathrm{T}_{\text {tabel }}$

$\begin{array}{cc}\text { Kelas Eksperimen } & \text { Kelas Kontrol } \\ 10,0882 & \mathrm{H}_{1} \text { Diterima } \\ 1,6669 & \end{array}$

Dari perhitungan tersebut didapatkan hasil $\mathrm{t}_{\text {hitung }}=10,0882$ sedangkan $\mathrm{t}_{\text {tabel }}$ $=1,6669$ dengan db 67. Dengan demikian diketahui bahwa $t_{\text {hitung }}<t_{\text {tabel }}$ yaitu 10,0882 > 1,6669 yang bearti $\mathrm{H}_{1}$ diterima dan $\mathrm{H}_{0}$ ditolak. Hal tersebut menunjukkan bahwa terdapat pengaruh signifikan penggunaan strategi socio scientific issues terhadap reflective judgment siswa.

\section{PEMBAHASAN}

Pendidikan sering diartikan sebagai usaha manusia untuk membina kepribadiannya sesuai dengan nilai-nilai didalam masyarakat dan kebudayaan. Menurut John Dewey dalam Hasbullah (2016) pendidikan adalah proses pembentukan kecakapan-kecakapan fundamental secara intelektual dan emosional kearah alam dan sesama manusia. Setiap kegiatan apapun bentuk dan jenisnya, sadar atau tidak sadar, selalu diharapkan kepada tujuan yang ingin dicapai. Bagaimanapun segala sesuatu atau usaha yang tidak mempunyai tujuan tidak akan mempunyai arti apa-apa. Dengan demikian, tujuan merupakan faktor utama yang sangat menentukan. Pendidikan sebagai suatu bentuk kegiatan manusia dalam kehidupannya juga menempatkan tujuan sebagai sesuatu yang ingin dicapai, baik tujuannya untuk menambah ilmu atau menjadikan moral seseorang yang lebih baik. Hal ini sesuai dengan firman Allah SWT dalam surat Thaaha: 114

Artinya : "Katakanlah (olehmu muhammad) "Ya Tuhanku, tambahkanlah kepadaku ilmu pengetahuan."

Setiap anak akan mengalami proses pendidikan secara alamiah, yaitu yang ia dapatkan dalam situasi pergaulan dangan orang lain pada umumnya pegaulan dengan orang tuanya pada khususnya dalam lingkungan budaya yang mengelilinginya. sebagaimana firman Allah SWT dalam surat Al-Nahl: 78

Artinya : "Dan Allah mengeluarkan kamu dari perut ibumu dalam keadaan tidak mengetahui sesuatupun, dan Dia memberi kamu pendengaran, penglihatan dan hati, agar kamu bersyukur".

Ayat diatas menjelaskan bahwa seorang anak terlahir didunia tanpa mengetahui sesuatupun, dan tugas keluargalah sebagai landasan awal untuk 
mengajarkan ilmu pengetahuan dan ahlak kepada anak. Sebagaimana firman Allah SWT dalan surat At Taubah : 122

Artinya : "Tidak sepatutnya bagi mukminin itu pergi semuanya (ke medan perang). mengapa tidak pergi dari tiap-tiap golongan di antara mereka beberapa orang untuk memperdalam pengetahuan mereka tentang agama dan untuk memberi peringatan kepada kaumnya apabila mereka telah kembali kepadanya, supaya mereka itu dapat menjaga dirinya"

Surat At Taubah menunjukkan bahwa memperdalam ilmu itu penting baik, terutama pada ilmu keagamaan. Karena dengan seseorang mengetahui suatu bidang ilmu, ia dapat mengajarkan ilmu tersebut kepada yang lain sehingga menjadikan suatu manfaat. Segala ilmu itu bersumber dari Allah, maka hendaknya manusia mendalami ilmu pengetahuan baik tentang agama maupun umum kemudian mengajarkan ilmu.

Tujuan utama pendidikan adalah menghasilkan kepribadian manusia yang matang secara intelektual, emosional, dan spiritual, karena itu komponen esensial kepribadian manusia adalah nilai dan kebajikan. Menurut Mulyana (2011) nilai dan kebajikan manusia adalah nilai dasar pengembangan kehidupan manusia yang memiliki peradaban, kebaikan, dan kebahagian secara individual maupun sosial.Pendidikan merupakan salah satu bidang yang memegang peranan penting dalam kehidupan, dalam proses pendidikan guru merupakan salah satu komponen sistem menempati posisi sentral, sehingga seorang guru dituntut untuk memiliki strategi yang tepat agar siswa dapat belajar secara efektif dan efesien mengena pada tujuan yang diharapkan. Menurut teori Piageat manusia dapat mengetahui adanya tahap-tahap perkembangan tertentu pada kemampuan berpikir anak di levelnya. Fatimah (2015) mengemukakan, bila dikaitkan dengan pembelajaran kita bisa memberikan perlakuan yang tepat bagi anak, misalnya dalam memilih cara penyampaian materi bagi siswa sesuai dengan tahap perkembangan kemampuan berpikir yang dimiliki oleh anak.

Pada proses pembelajaran IPA di SMPN 11 Bandar Lampung dari hasil observasi disekolah pada tahap awal penelitian, peneliti mewawancarai guru IPA yang ada disekolah. Dari hasil wawancara dan pengamatan selama proses pembelajaran berlangsung guru masih menggunakan strategi atau metode yang biasa dipakai disekolah seperti strategi ekspositori yang pembelajaran hanya fokus pada guru yang memberi informasi atau metode ceramah yang monoton. Hasil wawancara peneliti dengan salah satu guru IPA kelas IX, beliau menyatakan: "pada proses pembelajaran pada materi IPA guru biasa menggunakan metode ceramah, karena siswa lebih cepat menerima informasi daripada mencari informasi itu sendiri. Dibutuhkan strategi yang tepat untuk menumbuhkan rasa keingin tahuan siswa terhadap materi pelajaran sehingga siswa terlibat aktif dalam proses pembelajaran.Pembelajaran yang hanya fokus memberi imformasi dapat menyebabkan minat belajar siswa rendah karena proses pembelajaran kurang menarik, monoton, membatasi daya ingat dan keaktifan siswa (Sunarto,2015).sehingga saat pembelajaran siswa kurang aktif karena hanya mendengar apa yang disampaikan guru, melihat kondisi yang ada peneliti ingin melakukan penelitian yang menggunakan strategi pembelajaran socio scientific issues diharapkan saat proses pembelajaran siswa lebih aktif. Karena pada proses pembelajaran strategi ini menggunakan isu-isu sosial yang ada dimasyarakat 
dikaitkan dengan materi pembelajaran. Menurut Nuangchalerm (2016) pembelajaran sains tidak hanya mengacu pada materi, tetapi juga interaksi sosial terkait masyarakat dan sains yang perlu digabungkan dalam pembelajaran sains disekolah.

Pada saat observasi dilakukan peneliti bukan hanya mengamati proses pembelajaran dikelas untuk mengetahui strategi atau metode yang biasa dipakai guru, tetapi peneliti juga mengamati perilaku siswa disekolah tersebut dan mewawancarai beberapa siswa. Dari hasil pengamatan, menurut peneliti siswa di SMPN 11 Bandar Lampung pemikiran reflectivenya dan kepekaan mereka terhadap isu sosial yang ada dimasyarakat masih kurang. Untuk itu perlu menggunakan strategi yang tepat untuk dapat meningkatkan Reflective judgment siswa agar dalam menanggapi suatu masalah siswa lebih memikirkan secara matang mana yang baik dan buruk, bukan hanya menerima informasi dari orang lain. Sesuai dengan penelitian Djuwita dkk (2010) reflektif mencakup kemampuan untuk menganalisis fakta, mengenali silang pendapat dalam mencari kebenaran, membangun norma dan keteladanan dalam perilaku, dan menggunakan memori, pemikiran logis dan upaya yang sangat mendalam".

Dari seluruh populasi siswa disekolah, peneliti menggunakan sampel kelas IX, karena beberapa faktor yaitu uji populasi yang diperoleh berdistribusi normal dan homogen. Menurut peneliti siswa kelas IX secara pemikiran lebih matang dibandingkan siswa kelas VII dan VIII, sehingga dalam proses pembelajaran akan lebih cepat menerima atau menangkap apa yang disampaikan guru. Sampel yang digunakan kelas IX G dan IX H, sehingga menurut peneliti sampel sesuai dengan tujuan penelitian.

Penelitian ini menggunakan dua kelas, yaitu kelas IX G sebagai kelas eksperimen dengan jumlah siswa 35 orang dan menerapkan strategi Socio scientific issues, sedangkan kelas IX H sebagai kelas kontrol dengan jumlah siswa 34 orang menerapkan strategi ekspositori. Materi yang diajarkan pada penelitian ini adalah materi sistem reproduksi pada manusia, kemudian pada pertemuan terakhir kedua kelas tersebut diberikan soal untuk mengetahui reflective judgment siswa yang terdiri dari 10 soal yang disesuaikan dengan indikator yang telah ditentukan. Penelitian ini dilaksanakan pada 3 kali pertemuan dengan masingmasing 2 jam pelajaran pada setiap kali pertemuannya, pada pertemuan ketiga digunakan untuk posstes. Pada setiap pertemuan siswa melaksanakan diskusi kelompok yang terdiri dari 2 orang. Diskusi adalah strategi intruksional atau pengajaran yang melibatkan siswa untuk berbagi ide tentang satu topik umum.Didalam diskusi siswa dituntut untuk memikirkan satu topik secara mendalam dan lebih analitis, serta memberi kesempatan siswa untuk berpikir kritis (Agung, 2016).Pada saat proses, reflective Judgment siswa diasah dengan pertanyan-pertanyaan yang ada di LDS, pemilihan isu-isu ini berdasarkan pada kenyataan bahwa masalah sering tumbuh dimasyarakat, tapi itu menimbulkan dilema dalam membuat keputusan terkait masalah tersebut. Pada saat diskusi setiap kelompok dibagikan LDS (Lembar Diskusi Siswa) sebagai pendukung dalam proses pembelajaran.

Dalam proses pembelajaran dengan strategi socio scientific issues tahapan pembelajaran terdiri dari tahapan pendahuluan dimulai dengan salam dan berdoa, kemudianguru mengabsen kehadiran siswa. Selanjutnya tahapan subject matter knowledge, pada tahapan ini guru memberikan semacam motivasi agar siswa 
tertarik dengan materi pembelajaran yang akan dilaksanankan. Motivasi atau pernyataan dari guru sangat penting untuk menumbuhkan rasa keingin tahuan siswa terhadap materi yang akan dipelajari.Menurut Nurfauziyah (2015) melalui rasa ingin tahu, seseorang terdorong untuk mempelajari lebih lanjut tentang pengetahuan yang bermanfaat bagi dirinya maupun orang lain. Dilanjutkan pada tahapan informal reasoning guru memberikan pengetahuan awal mengenai materi yang akan dipelajari, guru akan membagikan LDS yang nantinya akan dikerjakan siswa. Pada tahapan decision making, dimana siswa diberi kesempatan untuk mendiskusikan LDS bersama teman sebangku untuk dipresentasikan, pada tahapan ini guru membimbing siswa dalam pengerjaan.

Pada tahapan character and reflectife judgment, pada tahap ini siswa mempresentasikan LDS didepan kelas. Pada tahapan ini guru dapat menilai karakter dan tahapan pemikiran reflective siswa dengan mendengarkan jawaban siswa terhadap isu sosial yang disajikan pada LDS. Pada tahapan argumentation, guru memberikan kesempatan kepada siswa lain untuk bertanya dan mengeluarkan pendapat sendiri mengenai isu sosial yang sedang dibahas kepada siswa yang mempresentasikan jawabannya. Pada tahapan ini siswa terlibat debat, ada yang setuju mapun tidak setuju.Di dalam debat harus disertaidengan pendapat-pendapat yang diawali dari analisis sebuah permasalahan sampai denganmempertahankan sebuah keputusan yang telah diambilnya disertai dengan argumen-argumen yanglogis dan rasional(Supratmi, 2011). Setiap pendapat yang dikeluarkan disertai dengan penjelasan untuk mempertahankan pendapat mereka yang menurut mereka benar. NRC menekankan seseorang untuk mampu memahami dan menciptakan argumen mengenai fenomena yang terjadi menggunakan logika ilmiah.

Pada tahapan moral reasoning yaitu penalaran moral, guru mengkonfirmasi pertanyaan maupun pernyataan dari siswa. guru meluruskan materi pelajaran dan kaitannya dengan masalah isu sosial yang ada dimasyarakat. Guru membimbing siswa menganalisa masalah sosial dan menilai terlebih dahulu yang akan dilakukan. Pada tahapan life experience, guru meminta siswa untuk menjelaskan pendapat masing-masing mengenai isu sosial atau lingkungan yang ada disekitar. Pada tahap ini guru meminta siswa menceritakan pengalaman pribadi siswa sendiri, baik yang dilihat maupun yang pernah didengar. Akan terlihat tanggapan atau pandangan siswa sendiri terhadap lingkungan sosial mereka. Menurut Hanurawan \& Waterworth dalam hanurawan (2015) tahapan perkembangan moral tertinggi dicapai apabila keputusan-keputusan moral seseorang didasarkan pada prinsip-prinsip etika yang bersifat komprehensif, konsisten dan universal. Pada tahapan terakhir yaitu kegiatan penutup guru mengapresiasi siswa yang telah berani mengelurkan pendapat, dilanjutkan dengan berdoa bersama dan diakhiri dengan salam.

Pada kelas eksperimen saat diskusi, suasana pembelajaran terlihat lebih aktif terlihat dengan siswa yang saling bertukar pendapat mengenai suatu isu-isu yang dipaparkan di LDS, berbeda halnya dengan proses pembelajaran pada kelas kontrol yang menerapkan strategi ekspositori dengan metode ceramah dan tanya jawab. Strategi lebih berpusat pada guru sehingga materi yang diterima hanya dari guru, dalam metode diskusi dan tanya jawab ini siswa kurang aktif karena pada LDS tidak dipaparkan isu-isu yang menarik seperti pada kelas eksperimen sehingga mereka dalam berdiskusi pasif. Hal ini sejalan dengan penelitian 
Rahmadani (2015) yang menyatakan siswa akan lebih aktif bila pembelajaran dikelas menggunakan strategi yang tepat dan materi yang menarik.

Pada kelas ekperimen pada pertemuan pertama membahas mengenai organ-organ reproduksi yang dikaitkan dengan isu-isu ilmiah yang ada dimasyarakat, pada LDS (Lembar Diskusi Siswa) ada 3 kegiatan yang dilakukan siswa yang mewakili setiap tahapan pemikiran Reflective yaitu pra reflevtive, quasy reflective dan reflective. pada tahap pemikiran pra reflevtive ciri utamanya adalah keyakinan tidak perlu pembenaran, maksudnya seseorang akan menerima langsung informasi yang didapat tanpa harus membuktikan atau menganalisa apa itu benar atau salah. Pada tahap quasy reflective ini pembenaran diperlukan dengan bukti, maksudnya dari sebuah informasi akan timbul pertanyaan pada diri sendiri apakah benar atau salah sehingga penerima informasi akan mencari data yang akurat. Pada tahap reflective seseorang sudah dapat menyimpulkan dan menjelaskan kepada orang lain, pada tahap ini seseorang dari penerima informasi menjadi pemberi informasi.

Pada kegiatan I untuk mengukur Pra relective siswa, dengan manyajikan isu-isu yang berkaitan dengan materi pembelajaran. Pada saat kegiatan I berlangsung dikelas terlihat siswa aktif memberikan komentar atau pendapat masing-masing kelompok, pada tiap baris tempat duduk siswa isu-isu yang disajikan berbeda sehingga dalam presentasi siswa mendapatkan informasi yang baru dan bertukar informasi. Dari hasil nilai LDS pada tahap pra reflective dapat dilihat pada lampiran nilai LDS nilai siswa cukup memuaskan artinya dalam mendapatkan suatu informasi siswa sudah dapat mengambil keputusan untuk diri mereka sendiri. Ada perbedaan nilai pada kelas kontrol pada tahap pra reflective, dilihat dari hasil diskusi dan LDS nilai kelas kontrol lebih rendah dari kelas eksperimen. Pada saat proses pembelajaran dikelas, siswa pada kelas kontrol terlihat kaku dan binggung. Pada proses diskusi dikelas kontrol terlihat berbeda suasana pada kelas eksperimen, pada kelas kontrol siswa saat mempresentasikan hanya menyampaikan isi dari lembar diskusi masing-masing. Dikarenakan perbedaan LDS pada siswa kelas kontrol dan kelas eksperimen yang menerapkan strategi pembelajaran socio scientific issues. Pada kelas kontrol siswa dalam memberikan jawaban hanya menurut pendapat mereka sendiri, tanpa memikirkan secara dalam masalah tersebut cukup hanya menerima informasi.

Pada kegiatan II mewakili tahapan pemikiran quasy reflective siswa diharapakan dapat memahami materi sedang dipelajari, dari hasil nilai LDS didapat pada kegiatan ini lebih meningkat dari pada tahap sebelumnya. Artinya siswa sudah dapat mengelolah data atau informasi yang disampaikan. Pada kelas kontrol pada kegiatan II perbedaan nilai dengan eksperimen tidak jauh berbeda. Pada kegiatan ini siswa diberikan arahan untuk menjelaskan materi yang diberikan, pada kelas kontrol dengan menggunakan strategi ekspositori pada kegiatan ini mereka sudah terbiasa mengolah data. Karena pada proses pembelajaran mereka lebih banyak menerima materi dari guru, kegiatan pembelajaran sepenuhnya diatur dan ditentukan oleh guru, siswa tidak dituntut menemukan materi tersebut (Mansyur, 2013).

Pada kegiatan III mewakili tahapan pemikiran reflective pada tahap ini siswa diharuskan sudah dapat menjelaskan dan menyimpulkan informasi yang didapat bahkan mampu mengeluarkan pendapat sendiri terhadap suatu masalah. Pada tahapan ini terlihat perbedaan cara pandang siswa terhadap suatu masalah 
antara kelas ekperimen dan kelas kontrol. Pada kelas ekperimen saat proses diskusi berlangsung, siswa terlihat berdiskusi aktif bersama teman sebangku. Sehingga antar siswa berani mengungkapkan pendapat sendiri dengan dasar ilmiah yang mereka ketahui, pada proses ini guru membantu siswa dalam meluruskan silang pendapat. Dalam beragumentasi siswa harus dapat memberikan alasan yang berdasarkan pengalaman belajarnya dan didukung oleh data yang benar, siswa dituntun untuk mengemukakan dan mempertimbangkan kemungkinan jawaban yang tepat untuk mendukung pernyataannya berdasarkan bukti. Pada proses pembelajaran mereka lebih tertarik membahas isu-isu sosial dan menimbulkan pertanyaan, sehingga setiap siswa aktif berbicara dan menceritakan pendapat mereka masing-masing. Hal ini sejalan dengan penelitian Silviana Hendri (2015) yang menyatakan, siswa akan termotivasi dalam pembelajaran sains untuk terlibat aktif mengemukakan pendapat dalam diskusi mengenai topik yang kontroversial melalui pengalaman yang dimilikinya".

Berbeda pada kelas eksperimen, pada kelas kontrol siswa cenderung pasif. Dalam berdiskusi hanya mengandalkan teman sebangkunya dalam menjawab pertanyaan, siswa menjawab pertanyaan hanya menurut mereka benar atau salah tanpa menganalisis isu-isu sosial ilmiah. Dari hasil nilai LDS didapat rata- rata nilai kelas eksperimen yaitu 73,25menunjukkan tahapan pemikiran yang muncul saat setelah pembelajaran dengan socio scientific issues. Ada hal-hal yang tampak menjadi kendala dalam proses pembelajaran pada kelas eksperimen yaitu siswa tampak canggung untuk mengikuti proses pembalajaran dengan strategi SSI. Kebiasaan siswa belajar dengan strategi yang diterapkan guru, membuat mereka lambat merespons skenario pembelajaran, untuk pertemuan pertama sudah terlihat kemampuan berpikir reflective siswa dapat dilihat dari aktifnya diskusi yang dilakukan saat proses pembelajaran dan hasil nilai LDS.Menurut Yusmiatidam rizkina (2013) siswa aktif adalah siswa yang terlibat secara fisik, psikis, intelektual dan emosional secara terus menerus dalam proses pembelajaran. Pada pertemuan kedua pada materi penyakit pada sistem organ reproduksi, siswa diberi LDS yang menyajikan beberapa macam penyakit menular, pada proses pembelajaran kedua ini terlihat siswa lebih siap dalam skenario pembelajaran karena sebelumnya mereka telah diterapkan strategi SSI. Sama seperti LDS pada pertemuan pertama, LDS pada pertemuan kedua ini juga terdapat 3 kegiatan yang setiap kegiatannya mewakili tahapan pemikiran reflective judgment. Pada kegiatan I siswa disajikan isu mengenai hubungan lawan Jenis, tugas siswa memberikan pendapat atau pandangan mereka mengenai isu tersebut. Dari hasil diskusi terlihat mereka antusias membahas isu ini karena berkaitan langsung dengan kehidupan siswa, terlihat beberapa siswa beradu pendapat mengenai isu ini mana yang baik dilakukan dalam menghadapi masalah tersebut.

Pada kegiatan ini reflective judgment siswa sudah dapat terlihat dilihat dari hasil jawaban mereka di LDS. Pada kegiatan II pada tahap pemikiran quasy eksperimen siswa dapat menjelaskan materi yang sedang dipelajari, pada tahap ini siswa diberikan waktu untuk mempresentasikan hasil diskusi. Di saat presentasi berlangsung ada umpan balik antara siswa yang mempresentasikan dan audiens, dari argument yang mereka keluarkan mengenai suatu masalah ada yang dapat menerima dan ada yang tidak setuju. Pada kegiatan ke III pada tahap pemikiran reflective, pada lembar LDS siswa dituntut untuk dapat menyimpulkan dan memberikan informasi kepada orang lain. Pada tahapan pemikiran reflective, ini 
tahapan terakhir dari reflective judgment dimana siswa sudah dapat memberikan informasi bahkan solusi atas sebuah masalah. Perbedaan terlihat jelas pada kelas eksperimen dan kelas kontrol, pada kelas kontrol siswa tidak aktif dan kaku, hal ini sesuai dengan penelitian Ana Maria (2014) yang menyatakan bahwa pembelajaran dengan menggunakan strategi yang hanya berfokus atau berpusat pada guru, siswa cenderung bosan dan kurang aktif dalam mengumpulkan informasi. Karena siswa terbiasa dengan menerima materi langsung dari guru, untuk berani beragumen mereka terlihat malu dan sebelummnya tidak diberikan stimulun menggunakan isu-siu sosial ilmiah didalam pembelajaran. Dari hasil data nilai LDS pada pertemuan kedua ini terjadi peningkatan dengan rata-rata nilai 74,54 terjadi peningkatan dari pertemuan pertama dan kedua, terlihat siswa lebih aktif pada proses pembelajaran menggunakan strategi SSI.

Dari data hasil penelitian pada kelas eksperimen setelah dilakukan posttes nilai rata-rata kelas eksperimen lebih baik dibandingkan kelas kontrol, pada kelas eksperimen reflective judgment mereka lebih meningkat dilihat dari hasil pengerjaan LDS dan diskusi selama dikelas berlangsung.Pada metode diskusi siswa diberi kesempatan untuk terlibat dalam proses pembelajaran. Sehingga guru hanya bersifat sebagai fasilitator. Siswa terlibat aktif dalam proses pembelajaran secara spontan. Keterlibatan ini berupa aktivitas belajar yang tidak hanya mendengar tetapi juga beraktivitas (Ayu, 2014). Siswa pada kelas eksperimen diterapkan strategi pembelajaran Socio scientific issues yang berkaitan dengan materi sistem reproduksi. Peningkatan ini disebabkan karena kelas eksperimen menggunakan strategi SSI, dimana siswa diharapkan untuk turut aktif dalam mengikuti tahapan-tahapan yang harus dilalui.

"Menurut Ratcliffe and Grace (2003) pada Journal of Research in Science Teaching, SSI menjadi sarana tidak hanya untuk meningkatkan ketertarikan siswa dibidang ilmu pengetahuan, tetapi juga menguatkan kemampuan umum sebagai tim kerja, pemecahan masalah dan literasi media”.

Berdasarkan hasil perhitungan diketahui rata-rata nilai akhir siswa kelas eksperimen berbeda dengan siswa kelas kontrol. Pada kelas eksperimen dalam proses pembelajaran menggunakan strategi socio scientific issues, diperoleh nilai rata-rata 74.42 sedangkan pada kelas kontrol yang menggunakan strategi ekspositori diperoleh rata-rata 70.73. hal ini menunjukkan bahwa pembelajaran menggunakan strategi SSI memberikan pengaruh terhadap reflective judgment siswa. kelas yang menerapkan SSI memiliki rata-rata nilai lebih tinggi dikarenakan siswa cenderung memiliki lebih banyak waktu diskusi dan debat hal ini seseuai dengan penelitian Y.N Pratiwi et.al(2016).

Faktor penyebab dari perbedaan rata-rata nilai kelas ekperimen dan kelas kontrol dikarenakan, dikelas eksperimen lebih berperan aktif dibadingkan dengan siswa yang berada pada kelas kontrol. Siswa diharuskan untuk mempersentasikan hasil diskusi mereka baik pada kelas eksperimen maupun kontrol dengan cara mereka sendiri, pada kelas eksperimen saat siswa lain mempersentasikan hasil diskusi mengenai isu yang telah dipaparkan terjadi timbal balik antar siswa dengan beberapa saling melempar pertanyaan bahkan berdebat mengenai isu yang telah dijabarkan. Sehingga siswa aktif dan berani mengeluarkan pendapat masingmasing, kegiatan pembelajaran seperti ini dapat meningkatkan Reflective Judgment siswa. Pada kelas kontrol saat melakukan diskusi pada materi yang 
sama tetapi tidak dipaparkan isu-isu mereka hanya mengandalkan teman sekelompok yang benar-benar memahami materitersebut. Selain itu kurangnya guru memvariasi metode pembelajaran menyebabkan siswa menjadi bosan dan kurang berminat (Sopyan, 2014).

Penerapan strategi pembelajaran Socio scientific issues pada kelas eksperimen memberikan pengalaman baru baru bagi siswa, pengalaman yang diperoleh adalah ilmu pengetahuan dan keaktifan siswa. Menurut penelitian yang telah dilakukan Troy D. Sadler (2004) jika guru ingin menggunakan isu socio scientific sebagai sarana agar ilmu lebih relevan dengan kehidupan siswa maka harus memilih isu-isu sosial lokal".

Dalam strategi SSI dapat meningkatkan Reflevtive Judgment siswa, siswa dituntut untuk mampu menganalisis suatu isu ilmiah dan sosial dari segi ilmu pengetahuan dan pandangan masyarakat awam. Kepekaan terhadap lingkungan sosial menimbulkan tindakan sosial individu yang merefleksikan sikap dan keyakinan seseorang terhadap objek sosial. Karena itu, kognisi, perasaan, dan tindakan merupakan aspek-aspek yang saling berkaitan satu sama lainnya membentuk suatu sikap, keyakinan, dan nilai moral.

Pemikiran Reflective perlu ditingkatkan karena siswa akan lebih percaya diri dalam mengeluarkan pendapat mereka, karena siswa memiliki dasar dan pemikiran matang mengenai suatu masalah sehingga seorang siswa dapat mengambil kesimpulan atau keputusan terhadap suatu masalah yang terjadi dilingkungan sekitarnya.Berdasarkan pembahasan tersebut dapat disimpulkan bahwa strategi socio scientific issues berpengaruh terhadap reflective judgment siswa. Hal ini sesuai dengan teori A.W Subiantoro (2015) yang menyatahkan bahwa penerapan strategi socio scientific issues berpengaruh lebih baik terhadap reflective judgment siswa. Dengan demikian dugaan yang menyatakan bahwa ada pengaruh interaksi antara strategi yang diterapkan terhadap reflective judgment siswa telah terbukti secara empirik dalam penelitian.

\section{SIMPULAN DAN SARAN}

Hasil penelitian ini menunjukkan bahwa penggunaan strategiSocio scientific issues berpengaruh terhadap Reflective judgment siswa kelas IX pada materi sistem reproduksi pada manusia

Berdasarkan hasil penelitian yang dilakukan tentang strategi pembelajaran Socio scientific issuesuntuk meningkatkan Reflective judgmentsiswa kelas IX SMPN 11 Bandar Lampung, maka penulis menggambarkan beberapa saran yang dapat digunakan sebagai tindak lanjut hasil penelitian ini yaitu: Guru hendaknya dituntut lebih kreatif dalam melaksanakan proses pembelajaran, selain strategi yang biasa digunakan guru yaitu strategi ekspositori. Guru juga perlu menggunakan strategi socio scientific issues dalam proses pembelajaran karena siswa akan lebih aktif dan guru bisa menanamkan moral yang baik kepada siswa.Bagi sekolah hendaknya lebih memperhatikan pengajar dan siswa agar bukan hanya nilai yang tinggi yang didapat siswa tapi sikap moral yang baik. Serta kepada peneliti lain akan melakukan penelitian, dapat melanjutkan penelitian serupa pada pokok bahasan lain, sehingga diperoleh informasi lebih luas tentang strategi socio scientific issues. 


\section{DAFTAR PUSTAKA}

Abdallah Salim Zo'bil. The Effect of Using Socio-Scientific Issues Approach in Teaching Environmental Issues on Improving the Students' Ability of Making Appropriate Decisions Towards These Issues. International Education Studies; Vol. 7 No. 8,2014.

Anas Sudijono. Pengantar Evaluasi Pendidikan. Jakarta: Raja Grafindo persada, 2013.

Anis Samrotul Tathifah. Penerapan Pembelajaran Socio Scientific Issues Melalui Metode Simposium Berbasis Lesson Study Untuk MeningkatkanKemampuan Berpikir Kritis Mahasiswa Pada Mata Kuliah Biologi Umum. Prosiding Seminar Nasional Pendidikan Biologi, 2015.

Arifin Zainal. Evaluasi pembelajaran. Bandung: Remaja Rosdakarya, 2009.

Aunnurahman. Belajar dan Pembelajaran. Bandung: Alfabeta, 2010

A.W. Subiantoro et.al. Pembelajaran Materi Dengan Socio Scientific Issues Dan Pengaruhnya Terhadap Reflective Judgment Siswa. Jurnal Pendidikan IPA Indonesia, 2013.

Bagod Sudjadi, Siti Laila. Biologi Sains dalam Kehidupan. Jakarta: Yudhistira, 2010.

Budiyono. Statistik Untuk Penelitian. Surakarta: UNS Press, Cet Ke-3, Ed Ke-2 2009.

Brendan E. Callahan. Enhancing nature of science understanding, reflective judgment, and argumentation through socioscientific issues. Graduate Theses and Dissertations, 2009.

Dana L. Zeidler et.al. Advancing Reflective Judgment Through Socioscientific Issues. Journal Of Research In Science Teacing Vol. 46 No.1, 2009.

Bryan H.Nicholas. Socioscientific Issues: Theory and Practice. Journal of Elementary Science Education. Vol. 21 No. 2, 2009.

Djamur Winatasasmita. Biologi Umum. Jakarta: Universitas Terbuka, 1999.

Depdiknas. Undang-Undang Tentang Sisdiknas Dan Peraturan Pelaksanaannya 2002-2004. Jakarta: Tamita Utama, 2003.

Mera Rizkina. Upaya Meningkatkan Keaktifan Siswa Dalam Diskusi Kelompok Melalui Layanan Bimbingan Kelompok Pada Siswa Kelas VIIIE di SMPN 19 Semarang. Skripsi Bimbingan Konseling Universitas Semarang, 2013.

Muhhibin Syah. Psikologi Belajar. Jakarta: PT. Raja Grafindo Persada, 2011.

Muhammad Mansyur. Perbedaan Hasil Belajar Materi Baterai Antara Model Pembelajaran Kooperatif dengan Model Pembelajaran Ekspositori. Skripsi Teknik Universitas Negeri Semarang, 2013.

Nana Sujana. Cara Belajar Siswa Aktif dalam Proses Belajar Mengajar. Bandung:Sinar Baru Algensindo, 1989.

..... Penelitian Hasil Proses Belajar Mengajar. Remaja Rosdakarya: Bandung, 2009.

Novalia, Muhamad Syazali. Olah Data Penelitian Pendidikan. Bandar Lampung: Anugrah Utama Rahaja, 2014.

Nurfauziyah et al. Penerapan Guided Inquiry untuk Meningkatkan Rasa Ingin Tahu Siswa Pada Pembelajaran Biologi di Kelas XI IPA SMA Al-Muayyad Surakarta Tahun Ajaran 2014/2015. Jurnal Pendidikan, 2016. 
Nunung Supratmi. Model Pembelajaran Telaah Yurisprudensi Pada Pembelajaran Keterampilan Berbicara Kritis Dengan Menggunakan Metode Debat Konfrontatif. Jurnal Pendidikan Vol. 12 No. 3, 2011.

Nuryani, R. Strategi Belajar Mengajar Biologi. Bandung :UPI, 2003.

Oemar Hamalik. Proses Belajarn Mengajar. Bandung : PT. Bumi Aksara, 2001.

Purwanti Windhy H, Sabar Nurohman, Widodo Setyo Wibowo. Model Integrated Science Berbasis Socio Scientific Issues Untuk Mengembangkan Thinking Skills Dalam Mewujudkan $21^{\text {st }}$ Century Skills. Jurnal Pendidikan Matematika Dan Sains, 2013.

Puspa Djuwita, et.al. Pengembangan Model Pendidikan Nilai Dalam Pembelajaran Bahasa Indonesia Untuk Meningkatkan Kemampuan Berpikir Reflektif Siswa SMP. Jurnal Pendidikan Triadik, 2010

Ramayulis. Ilmu Pendidikan Islam. Jakarta: Kalam Mulia, 2002.

Roestiyah N.K. Strategi Belajar Mengajar. Jakarta: Rineka Cipta.

Rohmat Mulyana. Mengartikulasi Pendidikan Nilai. Jakarta : Alfabeta. 2011

Riana Yani. Biologi 1 Kelas X SMA. Jakarta: Pusat Perbukuan Departemen Pendidikan Nasional, 2009

Silviana Hendri, Apriana Defianti. Membentuk Keterampilan Argumentasi Siswa Melalui Isu Sosial Ilmiah dalam Pembelajaran Sains. Prosiding Simposium Inovasi dan Pembelajaran Sains, 2015.

Sudjana. Metode Statistika. Bandung: Tarsito, 2005.

Sugiyono, Metode Penelitian Pendidikan. Bandung: Alfabeta, 2013.

...... Metode Penelitian kuantitatif dan Kualitatif dan R\&D. Bandung: Alfabeta, 2009.

Suharsimi Arikunto. Dasar-Dasar Evaluasi Pendidikan. Jakarta: Bumi Aksara, 2013.

Sumarna surapranata. Analisis, validitas, Reabilitas dan Interpreasi Hasil Tes. Bandung: PT Remaja Rosdakarya, 2004

Surakhman. pengantar interaksi mengajar belajar dasar dan teknik metodologipengajaran. Bandung: Tarsito, 1986.

Troy D.Sadler. Informal Reasoning Regarding Socioscientific Issues: A Critical Review of Research. Journal Of Research In Science Teaching vol.41 No.5, 2004.

Umar Tirtarahardja, La Sulo. Pengantar Pendidikan. Jakarta: Rineka Cipta, 2008.

Undang-Undang Sisdiknas Nomor 20 Tahun 2003, Pasal 3.

Wisnu Sunarto et al. Hasil Belajar Kimia Siswa Dengan Model Pembelajaran Metode Think-Pair-Share Dan Metode Ekspositori. Jurnal Pendidikan,2016.

Y.N Pratiwi. Socio ScientificIssues (SSI) In Reaction Rates Topicand Its Effecton The Critical Thinking Skills Of High School Students, Oktober 2016.

Zainal Arifin. Evaluasi Pembelajaran. Bandung: Remaja Rosdakarya, 2009. 